\title{
千葉大学大学院医学研究院 細胞治療内科学講座
}

竹本 稔

（日老医誌 $2017 ； 54 ： 199-201 ）$

\section{教室の沿革}

細胞治療内科学講座の前身である内科学第二講座（旧 第二内科) は, 1898 年 (明治 31 年), 千葉第一高等学 校医学部内科学教室として, 井上善次郎初代教授のもと に誕生した。 その後, 柏戸留吉教授, 佐々貫之教授, 堂 野前維摩郷教授, 田坂定孝教授, 斎藤十六教授, 熊谷朗 教授, 吉田尚教授へ継承され，1995 年に齋藤康教授が 就任された。従来の免疫アレルギー, 消化器, 血液, 糖 尿病, 内分泌, 脂質研究グループに加えて, 森聖二郎先 生 (現 東京都健康長寿医療センター, 臨床研究推進セ ンター部長）を中心に分子老化グループが創設され, 増 殖因子の細胞内シグナル伝達機構, 動脈硬化, 糖尿病大 血管障害の発症メカニズムに関する研究や遺伝性早老症 ウエルナー症候群に関する研究が行われ, 横手幸太郎先 生がこれを引き継いだ。 2001 年 4 月には千葉大学の大 学院大学化に伴い細胞治療学講座に名称が変更となり, 2004 年 4 月, 診療科再編に伴い旧第二内科として行っ てきた診療はアレルギー・膠原病内科，糖尿病・代謝 · 内分泌内科, 血液内科, 消化器内科としてそれぞれの研 究室で行われるようになった. 2008 年に齋藤教授が退 官され千葉大学長に就任された。 2009 年 5 月から横手 幸太郎先生が第 10 代の教授に就任. 2010 年 4 月からは 講座名が細胞治療内科学講座へと改称. 2014 年 7 月に は高齢者を包括的に診ることの必要性から附属病院に高 齢者医療センターが設立され活動を開始している。

現在の教室は, 横手幸太郎教授を筆頭として, 糖尿病・ 代謝 - 内分泌内科, 血液内科のスタッフ - 医局員 - 大学 院生を合わせ 50 名以上が診療・教育・研究にあたり, 千葉県内の主だった病院ならびに神奈川, 栃木, 静岡県 内の病院合わせて 20 以上の関連施設とも連携している.
当科の医師の中には内科学会認定内科専門医 8 名, 内分 泌指導医 3 名, 糖尿病学会指導医 3 名, 日本血液学会認 定指導医 5 名, 内分泌専門医 7 名, 糖尿病学会専門医 12 名, 血液学会認定専門医 8 名, 老年病学会専門医 3 名, 循環器専門医 1 名が含まれている（複数の専門医取得者 を含む).

人類に貢献できる世界水準の研究推進を第一目標と し，同時に「スペシャリストである前にジェネラリスト であれ」という旧第二内科の診療と教育の伝統を継承し, 全身を診ることのできる専門医の育成に注力しており， 血液, 糖尿病 - 代謝 - 内分泌内科, 老年病に扔ける研究 や診療に成果を上げている。

\section{教 育}

卒前教育に関して当教室では医学部学生に対し, 診断 学・内分泌・血液のユニット講義において, 疾患の基礎 病態や診断と治療に加え, 最近の先端医療に関する知見 を紹介している．クリニカルクラークシップでは，専門 医資格を有するスタッフの指導の下，当該分野の疾病に 罹患した症例と実地に接する機会を提供している．診察 技法を学び，診断に至る論理的思考法を身につけ，エビ デンスに基づいた治療選択を学べるよう体系だてた教育 を心がけている，症例を担当する学生は，準主治医的意 識を持つことを要求され，担当医による診断・治療のプ ロセスに常に立ち会うほか, 症例検討会において症例呈 示と討論を積極的に行う。独自の試みとして，受け持ち 症例に関連した学会への参加支援している.「老年病レク チャー」も医学部学生臨床実習中に 2 週毎に各グループ に対して行っている.

卒後教育/生涯教育は専門領域のみならず，内科全般

千葉大学大学院医学研究院細胞治療内科学講座 


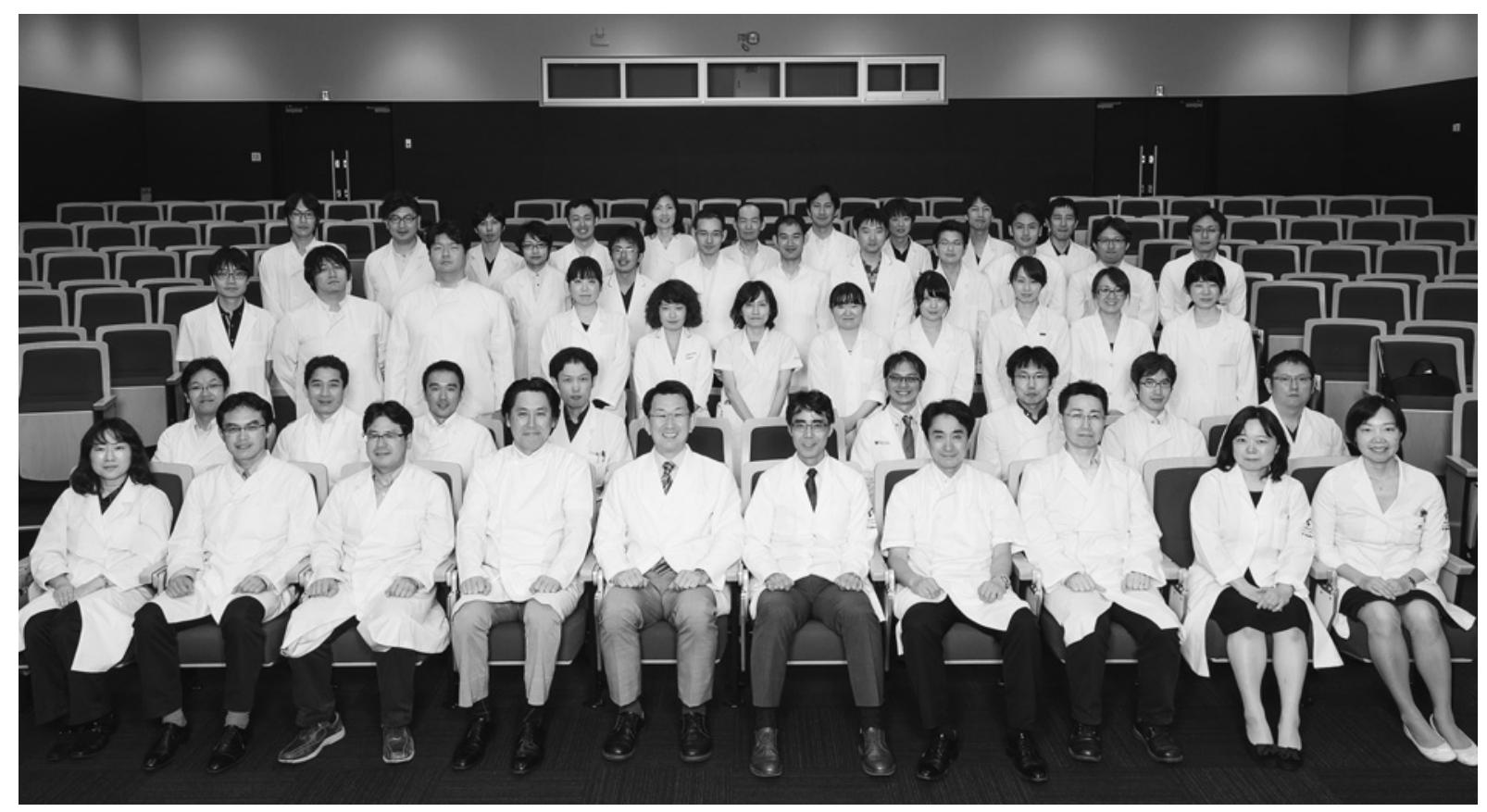

写真 1 千葉大学大学院医学研究院 細胞治療内科学講座の集合写真 最前列向かって左から 5 人目が横手幸太郎教授, 7 人目が筆者

に対する教育を心がけ，主として助教および病棟担当の 医員が担当している。週に一度のカルテ回診を実施し, 診断および治療選択の考え方からプレゼンターションの 技法までを研鑽している，回診にあたってはウィーク リーサマリーの作成が義務づけられ, 退院時には内科学 会認定医申請と同書式による退院サマリーを作成, それ ぞれ指導医による添削指導が行われる. 糖尿病, 内分泌・ 代謝疾患, 老年病に関するレクチャーが定期的に開催さ れ, 研修医は実施診察に必要な病態生理, 診断法, 治療 の最新知見などをアップデートすることができる。学会 報告, 認定医獲得のための指導も積極的に行っており, 数多くの学会において授賞している.

大学院教育は糖尿病, 内分泌, 代謝 - 老年病, 血液と いった各研究室を有し, 大学院生の日々の研究指導は 個々の研究室で行うともに, 週に一度は細胞治療内科学 教室全体のリサーチセミナーが行われ, グループの垣根 を越えて大学院生の研究テーマに関するディスカッショ ンが行われている. 特に大学院 3 年生以上は英語でプレ ゼンテーションとディスカッションを行っており, 普段 から英語に慣れ親しんでいる. 国内外の研究グループと も盛んに研究交流を行うとともに，その成果に関しても 遅滞なく国内外の学会に報告, 世界に通用する研究者の
育成に力を注いでいる，本講座の教員は, いずれも大学 院博士および修士課程学生に対する研究指導を実施して いる. 特筆すべきこととして, 講座の大学院生・ポスド ク系 5 名が, 今年度の日本学術振興会特別研究員 $(\mathrm{PD}$ : 1 名, DC2: 2 名, DC1：2名）に採択されている.

\section{診療と研究活動}

糖尿病・代謝 - 内分泌内科と血液内科は, ともに千葉 県における中核病院として, 県内の他病院と連携しなが ら最先端医療を展開している. 中でも高齢者関連として, 当教室ではこれまで遺伝性早老症 Werner 症候群の診療 と研究を行ってきた。早老症とは全身性に老化徴候が早 発・進展する疾患の総称である。代表例として知られる Hutchinson-Gilford Progeria 症候群 (HGPS) と Werner 症候群（WS）はいずれも希少であり，治療法はもとよ り患者の実態も不明である。このうち WS は思春期以 降に発症し, がんや動脈硬化のため 40 歳半ばで死亡す る常染色体劣性疾患で, 日本の推定患者数は約 2,000 名, 世界の報告の 6 割が日本人と我が国に多い. 平成 $21 \sim 25$ 年度の厚生労働科学研究費補助金 難治性疾患等政策研 究事業により, 我々はWSの診断基準改定と世界初の 
治療指針を完成し, 平成 26 年度にはWS 重症度分類を 作成し, 平成 27 年 7 月には指定難病に登録された。 ま たHGPSに関しても世界初の診断基準を作成している. この研究は日本各地の大学, 研究所と連携し, オールジャ パン体制で行っている。 日本医療研究開発機構研究費 難治性疾患実用化研究事業では, 臨床研究中核病院であ る千葉大学医学部附属病院の臨床試験部に「早老症レジ ストリー」事務局が設置されており，デー夕管理体制を 確立, 集積した症例の登録とフォローアップを開始して いる.さらに大阪大学の中神らが開発した新規創傷修復 ペプチドを用いたWSの難治性皮膚潰瘍治療臨床試験 との連携や広島大学との共同研究で疾患 iPS 細胞を用い た早老機序に関する研究も行っている.

難治性高脂血症の治療ではレシチンコレステロールア シルトランスフェラーゼ (LCAT) 欠損症に対して脂肪 細胞を用いた再生医療を行っている. 附属病院の未来開 拓センターにおいて, 脂肪細胞の特性に注目して, 患者 から脂肪細胞を分離培養, LCAT 遺伝子の導入後, 再 び患者に移植して治療する遺伝子治療体系が構築され, 2017 年 2 月に国内第 1 例目の移植が行われた.

急性期病院における臓器別診療の不十分な点を補い, 職種横断的にこれからの高齢者医療を考え，実践する目
的で設立された高齢者医療センターでは，高齢者に対す るポリファーマシー・フレイル外来を設置し, 一般の外 来から紹介された多剤・フレイルの問題を有する高齢者 を多職種で分析し適切なアセスメントシートを構築して 評価を行い, 抽出された問題に対し適切な介入を行い, 定期的なフォローアップを行うことでその介入効果を前 向きに観察している.

\section{おわりに}

当教室に関して概説した. 当科の目標は糖尿病・代 謝 - 内分泌内科学, 老年病学, 血液内科学各分野の疾患 に対する最高水準の治療を実施・開発するとともに，そ の診療に携わり指導にあたる良医を育成することにあ る. 特に老年医学では加齢という生理的変化に加え複数 臓器にまたがる疾患を有した高齢者を対象としているた め, 自らの専門分野を磨くとともに，それのみに限定さ れない「内科医」としての自覚を有する医師の養成を目 指している. 当教室に興味のある先生方にはホームペー ジを是非ご覧頂きたい. (http://www.m.chiba-u.jp/clas s/clin-cellbiol/) 